\title{
SEBUAH TINJAUAN TERKAIT HAK DASAR KAUM DIFABEL DALAM BINGKAI KESETARAAN WARGA NEGARA
}

\author{
Rahmad \\ Institut Agama Islam Palangka Raya, Kalimantan Tengah, Indonesia \\ rahmad@,iain-palangkaraya.ac.id \\ Received:11-06-2019; Revised: 14-06-2019; Accepted: 20-12-2019
}

\begin{abstract}
Disability is an integral part of society. They often get unfair treatment, for example in accessing social facilities that tend to be unfriendly to them. The state has issued a legal basis regarding brand protection, the state has juridically prepared related instruments. But the problem is the extent to which the rules are implemented in the community. This paper tries to examine the legal basis related to these problems which are trying to be related to the Pancasila ideology. If we look through the ideology of this nation in the description of the incarnations, it also shows how equality and justice are very concerned. Especially in the field of education, the relevant legal basis is complete and complete and appropriate to the level, for equitable access to education. Some of these facts certainly indicate that the Pancasila with its operation contained the points in its principle, then with its written constitution namely the 1945 Constitution both before the amendment and after the amendment This shows that the State with the Pancasila ideology and other legal bases has provided a proof of how Pancasila has proven as an ideology that puts human dignity and values into equal or no difference because of different origins or physical forms.
\end{abstract}

Keywords : Access, Disability, equality

\section{INTISARI}

Kaum disabilitas merupakan bagian masyarakat yang tidak terpisahkan. Mereka seringkali mendapat perlakuan yang tidak adil, misalnya saja dalam akses fasilitas sosial yang cenderung tidak ramah terhadap mereka. Negara telah mengeluarkan dasar hukum terkait perlindungan mereka, secara yuridis negara sudah mempersiapkan instrumen terkait. Tetapi yang menjadi permasalahan adalah sejauh mana implementasi aturan tersebut di masyarakat. Tulisan ini coba menelaah dasar hukum terkait permasalahan tersebut yang coba di kaitkan dengan ideologi Pancasila. Apabila kita telaah melalui ideologi bangsa ini dalam jabaran pada butir-butir penjelmaannya juga menunjukkan bagaimana kesetaraan dan keadilan menjadi sangat diperhatikan. Khusus bidang pendidikan, dasar hukum terkait telah lengkap ada dan lengkap serta sesuai tingkatan, untuk akses yang berkeadilan dalam bidang pendidikan. Beberapa fakta ini tentu menunjukkan bahwa Pancasila dengan operasionalisasinya yang tertuang dalam butir-butir pada silanya, kemudian dengan konstitusi tertulisnya yaitu Undang-Undang Dasar 1945 baik sebelum amandemen maupun sesudah amandemen. Hal tersebut menunjukkan bahwa Negara dengan ideology Pancasila dan dasar hukum lainnya telah memberi sebuah bukti bagaimana Pancasila telah membuktikan sebagai sebuah ideology yang meletakkan harkat dan martabat manusia menjadi sama atau tidak ada perbedaaan karena asal usul ataupun bentuk fisik yang berbeda.

Kata Kunci: Akses, Disabiltas, Kesetaraan. 


\section{A. PENDAHULUAN}

Indonesia sebagai sebuah Negara yang sejak masa awal kemerdekaan telah menjunjung tinggi Hak Asasi Manusia (HAM). Hal tersebut diwujudkan dengankesungguhan PPKI dalam memasukan pasal-pasal terkait HAM dalam konstitusi dasar tertulisnya, baik sebelum amandemen maupun setelah amandemen UUD 1945. Seiring semakin berkembangnya zaman serta bertambah kompleksnya permasalahan, maka negara menghadapi tantangan yang semakin besar pula. Al Qur'an pada surah Al Hujarat ayat 13 menjelaskan tentang posisi atau kesetaraan manusia.

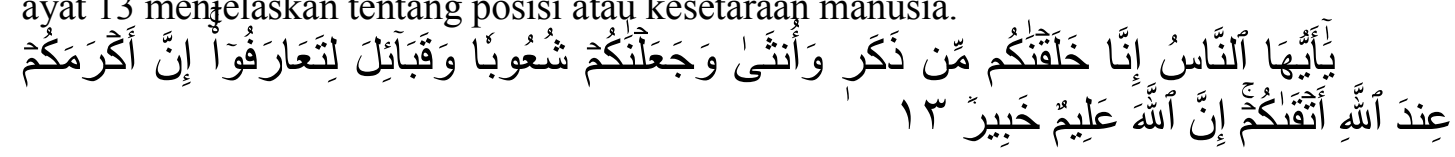

13. Hai manusia, sesungguhnya Kami menciptakan kamu dari seorang laki-laki dan seorang perempuan dan menjadikan kamu berbangsa-bangsa dan bersuku-suku supaya kamu saling kenal-mengenal. Sesungguhnya orang yang paling mulia diantara kamu disisi Allah ialah orang yang paling takwa diantara kamu. Sesungguhnya Allah Maha Mengetahui lagi Maha Mengenal

Agama telah menyatakan bahwa posisi dan kedudukan adalah yang sama dan tidakmelihat pad perbedaan fisik semata hanya pada derajat ketakwaan saja. Kesetaraan menjadi sebuah upaya Negara atau bahkan sebuah tantangan, yang telah disikapi dengan bangsa ini dengan baik dan sejatinya dapat menjadikan bangsa ini menjadi semakin baik untuk menjadi bangsa maju dan bermartabat dengan dasar ideologi Pancasila. Pada 18 Agustus 1945, PPKI melakukan persidangan pertama. Salah satu hasil sidang tersebut adalah, penetapan pembukaan hukum dasar (atau yang lazim kita sebut dengan Pembukaan UUD 1945) yang pada salah satu bagiannya atau tepatnya pada alinea keempat memuat rumusan sila Pancasila sebagai dasar negara. Hal ini menunjukkan bahwa Pancasila telah disahkan sebagai dasar negara.

Terkait tentang semakin kompleksnya permasalahan yang dihadapi bangsa. Hal tersebut akan menjadi sebuah "ujian" dengan harapan akan semakin mengokohkan Pancasila sebagai ideologi bangsa. Pancasila akan semakin menegaskan konsistensinya sebagai sebuah ideologi yang layak dan merupakan jawaban dari permasalahan bangsa ini. Dewasa ini tuntutan kesetaraan menjadi suatu keniscayaan dan keharusan. Seperti tuntutan kesetaraan gender atau ketidak adilan yang didapat oleh para wanita yang sering mendapat perlakuan dan tindakan kekerasan, atau pelecehan, dan tentu saja menyangkut akses bagi kaum difabel dalam menggunakan fasilitas umum yang setara atau berkeadilan.

Yuliati Hotifah menuliskan bahwa ketidak adilan gender dapat dan perlakuan diskriminasi terhadap perempuan dapat menjelma menjadi proses marjinalisasi (kondisi terpinggirkan), subordinasi (posisi diri selalu dibawah dan tidak berdaya), serta bertambahnya beban kerja. ${ }^{1}$ Wanita pun telah menjadi objek perhatian dari praktik kesetaraan, hal tersebut tertuang melalui deklarasi United Nations: Convention on the Elimination of All Forms of Discrimination Against Women. ${ }^{2}$ Penghormatan kepada bagian masyarakat yang boleh dikatakan lemah kembali diwujudkan dengan sebuah penghormatan terhadap kedudukan wanita atau penghapusan Segala Bentuk Diskriminasi Terhadap Wanita (Convention on the Elimination of All Forms of Discrimination Against

\footnotetext{
${ }^{1}$ Sumbulah Umi, ed., Spektrum Gender Kilasan Inklusi Gender Di Perguruan Tinggi (Malang: UIN Malang Press, 2008), h 161.

2 "United Nations: Convention on the Elimination of All Forms of Discrimination Against Women," International Legal Materials 19, no. 01 (January 1980): 33-45.
} 
Women $^{3}$ ). Hal ini direspons pemerintah. Bahkan pada masa orde baru (Presiden Soeharto) melalui Undang-Undang Nomor 7 Tahun 1984 tentang Pengesahan Konvensi mengenai perwujudan kesetaraan tersebut. Penghormatan kepada wanita ini kemudian diwujudkan Pemerintah pada masa Presiden Susilo Bambang Yudhoyono (SBY) melalui PP RI Nomor 65 Tahun 2005 tentang anti kekerasan terhadap perempuan.

Pemerintah juga mengeluarkan Undang-Undang Nomor 5 Tahun 1998 tentang Pengesahan Convention Against Torture and Other Cruel, Inhuman or Degrading Treatment or Punishment ${ }^{4}$ (Konvensi Menentang Penyiksaan dan Perlakuan atau Penghukuman Lain yang Kejam, Tidak Manusiawi, atau Merendahkan Martabat Manusia). Beberapa konvensi tersebut direspons Pemerintah melalui produk hukum untuk semakin menguatkan dan melindungi segenap warga negara tanpa terkecuali. Pada tataran dasar hukum sebagai upaya perlindungan telah dirintis negara. Tetapi yang menjadi permasalahan adalah apakah dalam tataran implementasi hal tersebut telah diketahui dan dilaksanakan oleh sebagian masyarakat.

Paham liberalisme dalam filsafatnya berkeyakinan mengenai pentingnya kemerdekaan setiap individu untuk mencapai setiap tujuan yang diharapkan. Semua manusia memiliki hak yang sama. ${ }^{5}$ Bagaimana posisi Indonesia, pemerintah menjamin hak yang sama bagi seluruh lapisan masyarakat tanpa terkecuali. Tetapi yang menjadi permasalahan adalah, apakah seluruh lapisan masyarakat dapat mengakses fasilitas yang diberikan oleh pemerintah tanpa terkecuali termasuk bagi kaum disabilitas. Isu kesetaraan bagi individu berkebutuhan khusus ini harus kita lihat melalui implementasinya atau dengan kata lain apakah fasilitas umum dan fasilitas sosial harus dan merupakan fasilitas (harus berkeadilan) yang dapat dikases dan ramah bagi kaum disabilitas.

Kaum Disabilitas telah diakui melalui UU No. 4 Tahun 1997 tentang penyandang cacat. Kata yang dipakai masih merupakan kata yang mempunyai konotasi "negatif" dan cenderung bermakna ada semacam belas kasihan. Selanjutnya perlindungan itu muncul pada UU No. 8 Tahun 2016 tentang penyandang disabilitas, yang menjadi sebuah pengakuan kedudukan dan dasar pemberian kemudahan terhadap akses yang diperoleh mereka. Pada tataran lokal atau provinsi dasar hukum perlindungan juga didapatken melalui Peraturan Daerah No. 17 Tahun 2013 tentang Perlindungan dan Pemenuhan Hak Penyandang Disabilitas.

Bulan ini (Desember) tepatnya pada tanggal 3 Desember telah ditetapkan PBB sebagai Hari Internasional Penyandang Cacat dan pada 10 Desember sebagai Hari Internasional Hak Asasi Manusia. Pada tataran internasional wujud keseriusan mengenai kesetaraan dan pengakuan HAM dituangkan dengan Resolusi Nomor A/61/106 yang dikenal dengan Convention on the Rights of Persons with Disabilities (Konvensi tentang Hak-Hak Penyandang Disabilitas) ${ }^{6}$ yang kemudian melahirkan UU No. 8 Tahun 2016 yang

3 Komnas Perempuan, "Siaran Pers Komnas Perempuan: Catatan Komnas Perempuan 33 Tahun Ratifikasi Konvensi CEDAW Di Indonesia,” July 24, 2017, https://www.komnasperempuan.go.id/reads-siaranpers-komnas-perempuan-catatan-komnas-perempuan-33-tahun-ratifikasi-konvensi-cedaw-di-indonesia,

https://www.komnasperempuan.go.id/reads-siaran-pers-komnas-perempuan-catatan-komnas-perempuan-33tahun-ratifikasi-konvensi-cedaw-di-indonesia.

${ }^{4}$ Convention against Torture and Other Crue l, Inhuman or Degrading Treatment or Punishment, 1984, . Konvensi ini salah satu dari 8 konvensi hak asasi yang diratifikasi Indonesia., https://www.ohchr.org/Documents/ProfessionalInterest/cat.pdf.

${ }^{5}$ As'ad Said Ali, Ideologi Gerakan Pasca Reformasi (Jakarta: LP3ES, 2012), h 47.

6 "Convention on the Rights of Persons with Disabilities (CRPD)" (United Nations, 2008), Indonesia juga telah meratifikasi konvensi ini pada tanggal 30 Maret 2007, untuk memastikan adanya hak yang sama bagi setiap warga Negara dan kaum disabilitas tanpa terkecuali., https://www.ohchr.org/Documents/Publications/Advocacy'Tool_en.pdf. 
pada prinsipnya merupakan produk hukum yang memperbaiki UU No. 4 Tahun 1997 tentang Penyandang Cacat.

Tulisan ini hanya mencoba menelaah tentang proses perwujudan kesetaraan bagi warga negara dengan lebih menekankan bidang pendidikan bagi warga negara, khususnya terkait kaum disabilitas di Indonesia, dalam mengupayakan peningkatan derajat mereka melalui pendidikan formal yang berkeadilan dan mempunyai asas kesetaraan.

\section{B. METODE}

Ketetapan MPR No. XVIII/MPR/1998, yang berdampak butir Pancasila mengalami perubahan dari 36 butir menjadi 45 butir dimana terdapat penambahan dan perubahan tentunya. Pada TAP MPR No. XVIII 1998 menjadi sebuah dasar tentang penjelmaan ideologi bangsa ini. Praktik kesetaraan tentu menjadi sebuah cita-cita bersama.

Tulisan ini merupakan sebuah kajian terkait praktik kesetaraan bagi masyarakat yang sering termarjinalkan dalam proses pelayanan publik. Praktik kesetaraan tersebut coba dikaitkan dengan dasar hukum yang telah ada.

Tulisan ini coba menelaah dasar hukum terkait permasalahan tersebut yang coba di kaitkan dengan ideologi Pancasila. Kami melakukan penelaahan dan pencarian sumber tertulis berupa sumber dan dasar hukum, artikel atau dokumen yang didapat dari studi kepustakaan ini untuk memperkuat argumentasi yang dihadirkan pada tulisan ini.

Permasalahan yang dikemukakan disini merupakan sebuah fenomena yang ada di masyarakat dimana dasar hukum yang telah ada, memiliki tujuan menjamin kesetaraan tersebut. Namun pada kenyataanya seringkali aturan dan dasar hukum terkait tidak diketahui sebagaian besar masyarakat. Untuk itulah tulisan ini mencoba merangkum hal-hal tersebut menjadi sebuah narasi yang mencoba untuk memaparkan permasalahan/fenomena tersebut dalam sebuah narasi yang sederhana ini.

\section{HASIL DAN PEMBAHASAN}

1. Perlindungan Negara

Tujuan negara menurut Emanuel Kant adalah membentuk dan mempertahankan hukum. Yang hendak menjamin kedudukan hukum dari individu-individu di masyarakat. Definisi lain negara hukum menurut Miriam Budiardjo adalah bonum publicum, common good, common weal (menciptakan kebahagiaan bagi rakyatnya). ${ }^{7}$ Pada prinsipnya tujuan negara hukum adalah menciptakan kedamaian dan hak asasi yang terlindungi. Manusia adalah makhluk istimewa yang diberkahi dengan hak dasar yang melekat yang kita kenal dengan Hak Asasi Manusia (selanjutnya disebut HAM).

Sejak berdirinya republik ini, para pendiri bangsa telah menekankan unsur-unsur penting yang harus dijunjung tinggi oleh sebuah bangsa yang merdeka dan beradab, yakni: kemanusiaan, keadilan, dan penghargaan antar bangsa yang berarti pula penghormatan terhadap internasionalisme. ${ }^{8}$ HAM merupakan sesuatu yang ada pada manusia sejak lahir dan tentu akan hilang saat meninggal dunia. Hal ini tentu merupakan suatu berkah yang telah ada pada setiap diri manusia. Konstitusi tertulis kita menyatakan setiap orang berhak mendapat kemudahan dan perlakuan khusus untuk memperoleh kesempatan dan manfaat yang sama guna mencapai persamaan dan keadilan.

Salah satu golongan yang cenderung mendapat perlakuan yang diskriminatif adalah kaum difabel/disabilitas. Diskriminatif tersebut biasanya berupa ketidak siapan fasilitas

\footnotetext{
${ }^{7}$ M. Iwan Satriawan and Siti Khoiriah, Ilmu Negara (Jakarta: PT. RajaGrafindo Persada, 2016), h 81-82.

8 Yudi Latif, Negara Paripurna Historisitas, Rasionalitas, Dan Aktualisasi Pancasila (Jakarta: PT Gramedia Pustaka Utama, 2011), h 239.
} 
untuk akses mereka. Akses terhadap fasilitas umum dapat dibagi menjadi dua yaitu: 1) fasilitas umum adalah fasilitas seperti jalan, halte dan trotor, kemudian 2) fasilitas social atau fasilitas yang diadakan oleh pemerintah atau pihak swasta yang dapat dimanfaatkan oleh masyarakat umum dalam lingkungan seperti sarana kesehatan umum, tempat ibadah, tempat olahraga dan tempat rekreasi.

Negara dituntut untuk melakukan tindakan-tindakan seperti menghilangkan hambatan-hambatan fisik para penyandang cacat, termasuk dalam hal ini adalah menetapkan kebijakan dan hukum yang mengatur dan menjamin akses penyandang cacat terhadap perumahan, gedung, transportasi publik, jalan dan semua lingkungan fisik lainnya. Kiranya juga perlu di catat bahwa pelayanan atas semua kebutuhan para penyandang cacat agar bisa setara dengan manusia lainnya bukan hanya menjadi tugas pemerintah semata, melainkan juga menjadi tugas masyarakat secara umum.

Terkait pelayanan publik, negara mengusahakan akses yang sama bagi seluruh lapisan dan bagian masyarakat atau warga negara Indonesia. Makna setiap warga Negara dalam asumsi disini adalah tidak ada pengecualian terhadapnya, termasuk kalangan berkebutuhan khusus atau kaum disabilitas atau difabel (diffirent ability) sebagai bagian dari rakyat Indonesia. . Disabel seperti kita ketahui bersama berasal dari kata disable, yaitu dis : tidak, able : bisa, mampu, sanggup. Jadi disable berarti : tidak bisa, tidak mampu, tidak sanggup, cacat, lumpuh, kata disable diucapkan menjadi kata disabel, lalu di bahasa Indonesiakan menjadi disabilitas yang berarti : penyandang cacat fisik.

Aksesibilitas adalah kemudahan yang disediakan bagi penyandang cacat guna mewujudkan kesamaan kesempatan dalam segala aspek kehidupan dan penghidupan. ${ }^{9}$ Rule 5 Accessibility States should recognise the overall importance of accessibility in the process of the equalisation of opportunities in all sphere of society. For persons with disabilities of any kind, states should (a) introduce programmes of action to make the physical environment accessible; and (b) undertake measures to provide access to information and communication. ${ }^{10}$ Apabila kita terjemahkan, pasal tersebut mencoba melindungi atau dengan kata lain negara harus mengakui dan menjamin aksesibilitas para penyandang cacat melalui dua hal yakni: pertama, menetapkan program-program aksi untuk mewujudkan aksesibilitas fisik penyandang cacat; kedua, melakukan upaya-upaya untuk memberikan akses terhadap informasi dan komunikasi para penyandang disabilitas. Aksesibilitas atau kemudahan dalam memanfaatkan fasilitas atau sarana prasarana menjadi sebuah keinginan bersama, dan negara telah mengupayakan hal tersebut.

Bagi penyandang disabilitas akses yang memudahkan mereka tentu menjadi sebuah harapan dan bentuk penghargaan bagi kemandirian mereka. Akses yang mudah tersebut tentu bukan sebuah bentuk belas kasihan pemerintah ataupun masyarakat, tetapi hal tersebut menjadi upaya untuk meletakkan martabat yang sama pada seluruh bagian masyarakat. Akses menjadi kunci dalam pelayanan umum bagi disabilitas atau dalam pengertian yang ditulis pada $\mathrm{UU}^{11}$ tentang disabilitas disebutkan dengan kata aksesibilitas yang didefinisikan sebagai sebuah kemudahan yang disediakan untuk penyandang disabilitas guna mewujudkan kesamaan kesempatan.

Setiap orang berhak bebas dari perlakuan yang bersifat diskriminatif atas dasar apapun dan berhak mendapatkan perlindungan terhadap perilaku yang bersifat

9 Peraturan Pemerintah Nomor 43 Tabun 1998 Tentang Upaya Peningkatan Kesejabteraan Sosial Penyandang Cacat, 1998th ed. (Jakarta: Sekretaris Negara, n.d.), Pasal 1 (4), https://www.bphn.go.id/data/documents/98pp043.pdf.

10 World Confenderation for Physical Therapy, The Standard Rules on the Equalisation of Opportunities for

Persons with Disabilities (New York: United Nations, 1993), https://www.wcpt.org/sites/wcpt.org/files/files/END_UN_Rules_equalisation_persons_disabilities_2015.pdf.

11 Undang-Undang No 8 Tabun 2016 Tentang Penyandang Disabilitas (Jakarta: Kementrian Hukum dan HAM, 2016), Pasal 1 (8). 
diskriminatif itu. ${ }^{12}$ HAM menjadi sebuah anugerah Tuhan bagi manusia karena merupakan perwujudan kesetaraan dalam berbagai hal. Negara telah mengatur dan memuat hak dasar tersebut dalam konstitusi. Hal yang patut kita telaah bersama adalah bagaimana pelaksanaan atau penerapan hal tersebut, utamanya kepada masyarakat yang cenderung terpinggirkan atau kurang mendapat akses yang baik dalam memanfaatkan fasilitas umum, sosial atau dapat memperoleh hak yang sama dalam berbagai hal.

Selanjutnya dijelaskan bahwa setiap penyandang cacat berhak memperoleh : (1) pendidikan pada semua satuan, jalur, jenis, dan jenjang pendidikan; (2) pekerjaan dan penghidupan yang layak sesuai jenis dan derajat kecacatan, pendidikan, dan kemampuannya; (3) perlakuan yang sama untuk berperan dalam pembangunan dan menikmati hasil-hasilnya; (4) aksesibilitas dalam rangka kemandiriannya; (5) rehabilitasi, bantuan sosial, dan pemeliharaan taraf kesejahteraan sosial; dan (6) hak yang sama untuk menumbuh kembangkan bakat, kemampuan, dan kehidupan sosialnya, terutama bagi penyandang cacat anak dalam lingkungan keluarga dan masyarakat. ${ }^{13}$

Peraturan Pemerintah Nomor 43 Tahun 1998 tentang Upaya Peningkatan Kesejahteraan Sosial Penyandang Cacat, yang isinya menyerukan kesamaan kesempatan dan penyediaan aksesibilitas yang berbentuk nonfisik dan fisik. Hal ini semakin diperkuat dengan surat edaran Menteri Sosial Republik Indonesia No. A/A164/VIII/2002/MS, tanggal 13 Agustus 2002 yang memperjelas kemudahan yang diberikan kepada para penyandang cacat, serta upaya penyediaan aksesibilitas yang berbentuk nonfisik dan fisik dapat dikoordinasikan pelaksanaannya, yang meliputi hal-hal sebagai berikut: (1) Penyediaan fasilitas/ aksesibilitas penyandang cacat pada gedung dan sarana umum seperti yang telah dilaksanakan oleh sebagian instansi/lembaga di Indonesia; (2) Pembangunan gedung baru agar disediakan aksesibilitas bagi penyandang cacat dengan memperhitungkan proses rancang bangun sesuai Kepmen PU No. 468/KPTS/1998 tanggal 1 Desember 1998.

Pelaksanaan dan Pemenuhan hak penyandang disabilitas bertujuan mewujudkan penghormatan, pemajuan, pelindungan dan pemenuhan hak asasi manusia serta kebebasan dasar penyandang disabilitas secara penuh dan setara. ${ }^{14}$ Indonesia menegaskan bahwa penyandang cacat merupakan bagian masyarakat Indonesia yang juga memiliki kedudukan, hak, kewajiban, dan peran yang sama. Mereka juga mempunyai hak dan kesempatan yang sama dalam segala aspek kehidupan dan penghidupan. Mengenai penghormatan dan perlindungan tersebut pemerintah bahkan telah mengeluarkan pedoman teknis fasilitas dan aksesibilitas pada bangunan gedung dan lingkungan yang dikeluarkan menteri pekerjaan umum telah menggambarkan akses kemudahan yang diberikan kepada penyandang disabilitas.

Selain dari fasilitas dan akses, tentu kita juga perlu memperhatikan pelayanan publik yang juga langsung menyentuh seluruh bagian ataupun lapisan masyarakat. Pemerintah telah mengeluarkan UU No. 25 Tahun 2009 yang memiliki tujuan sebagai sebuah rambu dasar dalam hal pelayanan publik bagi seluruh warga negara, termasuk kaum disabilitas didalamnya yang tentu saja memiliki keterbatasan dalam hal fisik dan psikologis untuk pemenuhan hak-hak dasar mereka.

\footnotetext{
12 “Undang-Undang Dasar RI 1945” (Sekretariat Negara, n.d.), Pasal 28 I (2), http://jdih.pom.go.id/uud1945.pdf.

13 Undang-Undang No. 4 Tabun 1997 Tentang Penyandang Cacat (Jakarta: Mentri Sekretaris Negara, 1997), Pasal 6, http://www.kpai.go.id/files/uu/UU-NOMOR-4-TAHUN-1997-TENTANG-PENYANDANGCACAT.pdf.

14 Undang-Undang No 8 Tabun 2016 Tentang Penyandang Disabilitas, Pasal 3.
} 
Pelayanan publik mempunyai asas dalam pelaksanaan tersebut. Pada asas ketiga ${ }^{15}$ disebutkan tentang kesamaan hak, yang dijelaskan sebagai sebuah asas yang tidak diskriminatif dalam arti tidak membedakan suku, ras, agama, golongan, gender dan status ekonomi, bahkan pada asas ketujuh disebutkan asas persamaan perlakuan atau tidak diskriminatif, perlakuan yang didapat dari para pelayan publik sama rata dan tidak melihat dari strata sosial masyarakat tersebut. Selain tentu mementingkan asas yang pertama yaitu asas kepentingan umum yang didefinisikan sebagai kepentingan orang banyak yang untuk mengaksesnya, tidak mensyaratkan beban tertentu.

Layanan publik yang baik, tentu akan memunculkan semangat perbaikan dan membuat munculnya pengelolaan pemerintahan secara baik, akuntabilitas dan terpercaya. Badan Perencanaan pembangunan Nasional (Bappenas) menambahkan prinsip dalam pelaksanaan good governance seperti: 1) wawasan ke depan, 2) demokrasi, 3) Profesionalisme dan kompetensi, 4) desentralisasi, 5) kemitraan dengan dunia usaha dan masyarakat, 6) komitmen pada pengurangan kesenjangan, 7) komitmen pada lingkungan hidup, 8) komitmen pasar yang fair. Khusus pada nomor 6 tentu bukan persoalan mudah. Itu sebabnya menciptakan kesetaraan dan persamaan diartikan pula dengan mereduksi berbagai perlakuan diskriminatif yang menciptakan kesenjangan dalam kehidupan bermasyarakat. ${ }^{16}$ Hal ini akan menciptakan adanya perbaikan dalam sistem layanan dan akan memunculkan kepentingan yang harus didahulukan dari kepentingan-kepentingan yang lain dengan tetap memperhatikan proporsi pentingnya dan tetap menghormati kepentingan-kepentingan lain.

Pemikiran Amartya Sen (1999) menyebutkan bahwa pembangunan dapat dilihat sebagai perluasan kemerdekaan nyata yang dinikmati masyarakat (development can be seen as aprocess of expanding the real freedom that people enjoy). Menurut Sen dengan menekankan pada kemerdekaan manusia, membuat pandangan ini berbeda dengan pandangan-pandangan sempit pembangunan yang hanya menekankan pada pertumbuhan ekonomi, peningkatan pendapatan, industrialisasi, kemajuan teknologi dan modernisasi sosial. $^{17}$

Data terkait jumlah penyandang disabilitas di Indonesia sebanyak 6.008 .661 orang. Dari jumlah tersebut sekitar 1.780.200 orang adalah penyandang disabilitas netra, 472.855 orang penyandang disabilitas rungu wicara, 402.817 orang penyandang disabilitas grahita/intelektual, 616.387 orang penyandang disabilitas tubuh, 170.120 orang penyandang disabilitas yang sulit mengurus diri sendiri, dan sekitar 2.401 .592 orang mengalami disabilitas ganda. ${ }^{18}$ Kaum disabilitas sebagai kelompok rentan tentu harus diperhatikan dan memperoleh akses fasilitas yang mudah bagi mereka, namun dengan tetap memperhatikan keadilan bagi masyarakat berkebutuhan khusus (kaum disabilitas) selain wanita dan anak-anak atau lansia sebagai kelompok prioritas.

Sebagai contoh dua provinsi di Kalimantan yaitu Kalimantan Selatan dan Kalimantan Tengah memiliki kaum difabel/disabilitas yang cukup tinggi. Kalimantan Tengah merupakan daerah tertinggi atau peringkat pertama di pulau Kalimantan dalam hal prevalensi disabilitas. Berdasarkan Data Susenas Kalimantan Tengah memiliki prosentase

15 UU No. 25 Tabun 2009 Tentang Pelayanan Publik (Jakarta: Kementrian Hukum dan HAM, 2009), Bagian Kedua Pasal 4 Terkait Asas Pelayanan Publik, http://bphm.unila.ac.id/images/bphm/doc/UU-No-25Thn-2009-ttg-Pelayanan-Publik.pdf.

16 A. Ubaedillah, Pendidikan Kewarganegaraan (Civic Education) Pancasila, Demokrasi Dan Pencegahan Korupsi, vol. Cetakan ke-3 (Jakarta: Prenadamedia, 2016), h 214-216.

66.

17 Warjio, POLITIK PEMBANGUNAN Paradoks, Teori, Aktor Dan Ideologi (Jakarta: Kencana, 2016), h

18 Survei Sosial Ekonomi Nasional 2013 (Jakarta: Direktorat Statistik Kesejahteraan Rakyat dan Direktorat Statistik Harga - Badan Pusat Statistik, 2014), https://microdata.bps.go.id/mikrodata/index.php/catalog/220. 
penyandang disabilitas sebesar $2.39 \%$ dan menempati posisi 15 , sedangkan Kalimantan Selatan pada posisi 19 dengan prosentase $2.35 \%$.

Kaum difabel/disabilitas merupakan bagian masyarakat yang cukup besar. Data melalui buletin jendela data dan informasi kesehatan dalam Susenas 2012 disebutkan penduduk Indonesia yang menyandang disabilitas sebesar 2,45\% dari total keseluruhan penduduk Indonesia. Jumlah yang besar ini menjadikan kaum difabel/disabilitas menjadi bagian yang cukup besar dan penting bagi bangsa ini.

Hal ini menunjukkan bahwa angka prosentase penyandang disabilitas di Kalimantan Tengah, Selatan dan atau Indonesia secara umum memberi gambaran bagi kita bersama bahwa golongan ini memang layak untuk diperhatikan, misalnya saja untuk akses pendidikan sebagai salah satu layanan umum juga harus menjadi pendidikan dengan akses yang adil dan merata, misalnya bagi kaum difabel/disabilitas.

\section{Pendidikan Bagi Kaum Disabilitas}

Allah telah menyatakan dalam Al Qur'an surah Al Mujadalah ayat 11 yaitu

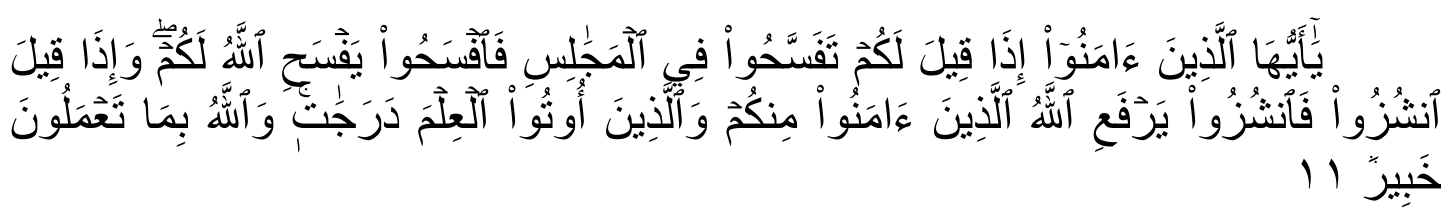

11. Hai orang-orang beriman apabila dikatakan kepadamu: "Berlapang-lapanglah dalam majlis", maka lapangkanlah niscaya Allah akan memberi kelapangan untukmu. Dan apabila dikatakan: "Berdirilah kamu", maka berdirilah, niscaya Allah akan meninggikan orang-orang yang beriman di antaramu dan orang-orang yang diberi ilmu pengetahuan beberapa derajat. Dan Allah Maha Mengetahui apa yang kamu kerjakan.

Pentingnya pendidikan telah dinyatakan dengan ayat ini, negara melalui konstitusi dasar kita telah menjamin adanya hak dasar dalam bidang pendidikan. Hak dalam pendidikan tertulis bahwa setiap warga negara berhak mendapat pendidikan. Selanjutnya juga tertulis bahwa setiap warga negara wajib mengikuti pendidikan dasar dan pemerintah wajib membiayainya. ${ }^{19}$ Konstitusi kita menjamin hak tersebut tetapi seringkali sekolah reguler belum mengakomodir hal tersebut. Penyiapan fasilitas terkait tentu harus memeperhatikn dasar hukum yang menyertainya. Untuk masalah fasilitas ramah disabilitas dapat di lihat melalui Peraturan Menteri Pekerjaan Umum (Permen PU) No. 30/PRT/M/2006 Tentang Pedoman Teknis Fasilitas dan Aksesibilitas Pada Bangunan Gedung dan Lingkungan.

Sekolah-sekolah dapat mulai melakukan pendidikan dini, sosialisasi, dan latihan simulasi aksesibilitas disabilitas. Pemerintah harus menggiatkan pendidikan dan pelatihan guna menumbuhkan kesadaran masyarakat terhadap pentingnya aksesibilitas untuk semua. ${ }^{20}$ Pendidikan memang merupakan sebuah solusi dalam perkembangan manusia dan kebudayaannya. Ada program khusus untuk mengakomodir hal ini melalui sistem pendidikan inklusif. Tetapi pendidikan inklusif seperti dijelaskan ${ }^{21}$ adalah sistem

19 Undang-Undang Dasar 1945 (Jakarta: Sekretariat Negara, 2002), Pasal 31 ayat 1 dan 2, http://jdih.pom.go.id/uud1945.pdf.

20 Nirwono Joga, “Mewujudkan Kota Ramah Disabilitas," Investor Daily, 2016, Beliau merupakan Koordinator Kemitraan Kota Hijau, http://id.beritasatu.com/home/mewujudkan-kota-ramahdisabilitas/148721.

21 Peraturan Menteri Pendidikan Nasional No. 70 Tentang Tentang Pendidikan Inklusif Bagi Peserta Didik Yang Memiliki Kelainan Dan Memiliki Potensi Kecerdasan Dan/Atau Bakat Istimewa (Jakarta: Kementrian Pendidikan Nasional, 2009), Pasal 1, http://kelembagaan.ristekdikti.go.id/wp-content/uploads/2016/11/Permen-No.-702009-tentang-pendidiian-inklusif-memiliki-kelainan-kecerdasan.pdf. 
penyelenggaraan pendidikan yang memberikan kesempatan kepada semua peserta didik yang memiliki kelainan dan memiliki potensi kecerdasan dan/atau bakat istimewa untuk mengikuti pendidikan atau pembelajaran dalam satu lingkungan pendidikan secara bersama-sama dengan peserta didik pada umumnya.

Melalui pendidikan inklusi, anak berkebutuhan khusus di didik bersama-sama anak lainnya (yang tidak memiliki keterbatasan) untuk mengembangkan dirinya. Pendidikan inklusif merupakan suatu solusi tetapi bukan solusi utama, karena tidak ada sosialisasi yang menyeluruh yang diharapkan untuk membuat kaum difabel menjadi berinteraksi dengan baik kepada peserta didik lain yang tidak memiliki kendala dalam geraknya.

Semangat non-diskriminasi telah muncul di dalam kebijakan sektor pendidikan. Namun di tahap pelaksanaan, hak untuk diperlakukan secara setara di sekolah umum tidak dapat berjalan. Pendidikan konvensional melihat bahwa masalah disabilitas sebagai hambatan siswa untuk memperoleh pencapaian sebagaimana 'siswa normal'. ${ }^{22}$ Peraturan Pemerintah No. 17 Tahun 2010 misalnya pasal 69 juga mengamanatkan bahwa setiap tingkatan pendidikan formal harus menerima peserta didik yang berkelainan.

Pada tataran lokal perlindungan terhadap disabilitas telah ada melalui Peraturan Daerah No. 17 Tahun 2013 Pemerintah Provinsi Kalimantan Selatan sehingga menciptakan suatu lingkungan pendidikan secara bersama-sama. Perda ${ }^{23}$ tersebut menyebutkan bahwa setiap penyelenggara pendidikan pada semua jalur, jenis dan jenjang pendidikan memberikan kesempatan dan perlakuan yang setara dan berkewajiban menerima peserta didik Penyandang Disabilitas. Hal ini menunjukkan bahwa aturan yang ada mulai dari UUD, UU, PP, Permen bahkan sampai Perda sudah mengatur hal terkait. Tetapi ada temuan menarik dari hasil ${ }^{24}$ hingga kini, $90 \%$ dari 1,5 juta anak dengan disabilitas justru tidak dapat menikmati pendidikan. Hal ini tentu menjadi sebuah pekerjan besar terkait satu bidang yaitu, bidang pendidikan sebagai sebuah hak dasar yang memang harus dipenuhi oleh negara.

Perda tersebut juga menegaskan adanya sebuah keharusan dalam memberi pelayanan yang tetap mengedepankan kualitas yang harus disesuaikan dengan potensi penyandang disabilitas yang juga merupakan peserta didik. Hal ini merupakan sebuah sinyal bahwa sekolah reguler juga harus mengakomodir atau menerima peserta didik disabilitas. Pendidikan menjadi sebuah salah satu sarana untuk menghilangkan diskriminasi. Pendidikan tentu menjadi ujung tombak tersebut. UU Sisdiknas ${ }^{25}$ pada pasal tersebut memberikan sebuah komitmen pemerintah untuk menyelenggarakan pendidikan yang adil dan layak tanpa diskriminasi. Peningkatan aksesibilitas layanan pendidikan yang merata, bermutu dan proporsional tentu menjadi sebuah keharusan agar pendidikan yang setara menjadi sebuah akses yang bisa diterima siapapun, termasuk kaum disabilitas.

\section{Penghormatan Manusia Dalam Pancasila}

Ideologi bangsa ini telah menunjukan perhatian besar dalam hal kesetaraan. Apabila kita telaah pada sila kedua kita dapat membaca pada butir pertama yang merupakan jabaran sila kedua tersebut bahwa ada pengakuan atau perlakuan terhadap manusia sesuai dengan harkat dan martabatnya sebagai makhluk Tuhan YME, butir kedua

\footnotetext{
22 Irwanto et al., Analisis Situasi Penyandang Disabilitas Di Indonesia: Sebuab Desk Review (Jakarta: Pusat Kajian Disabilitas FISIP UI, 2010), h 18.

23 Peraturan Daerah Provinsi Kalimantan Selatan Nomor 17 Tentang Perlindungan Dan Pemenuban Hak Penyandang Disabilitas (Banjarmasin: Pemerintah Provinsi Kalimantan Selatan, 2013), Pasal 9 (1), http://banjarmasin.bpk.go.id/wp-content/uploads/2014/09/PERDA-NO-17-TAHUN-2013DISABILITAS.pdf.

24 et al., Analisis Situasi Penyandang Disabilitas Di Indonesia: Sebuah Desk Review, h 14.

25 Undang-Undang No 20 Tahun 2003 Tentang Sistem Pendidikan Nasional (Jakarta: Kementrian Pendidikan Nasional, 2003), Pasal 4(1), Pasal 11(1), Pasal 12 (1b), https://kemenag.go.id/file/dokumen/UU2003.pdf.
} 
mengakui persamaan derajat, persamaan hak, dan kewajiban asasi setiap manusia, tanpa membeda-bedakan suku, keturunan, agama, kepercayaan, jenis kelamin, kedudukan sosial, warna kulit dan sebagainya.

Pada butir ketiga yaitu mengembangkan sikap saling mencintai sesama manusia. Butir keempat yaitu mengembangkan sikap saling tenggang rasa dan tepa selira. Pada butir kelima mengembangkan sikap tidak semena-mena terhadap orang lain dan pada butir keenam yaitu menjunjung tinggi nilai-nilai kemanusiaan.

Pada jabaran butir yang terdapat pada sila kedua sudah sangat jelas akan adanya suatu rumusan penghormatan terhadap nilai-nilai kemanusiaan. Hal ini menunjukkan bahwa pada aspek butir yang terdapat pada sila kedua Pancasila telah dengan sangat jelas mendudukan posisi manusia sebagai makhluk yang memmpunyai kedudukan pada semestinya tanpa ada perbedaan baik suku, agama, dan bahkan bentuk fisik tentunya.

Keadilan sosial bagi seluruh rakyat Indonesia bertujuan untuk mewujudkan kesejahteraan bagi seluruh rakyat Indonesia. Ini berarti tiap-tiap orang berhak menikmati kehidupan yang layak sebagai manusia yang terhormat. ${ }^{26}$ Keadilan sosial adalah adanya keseimbangan dan pembagian yang proporsional atas hak dan kewajiban setiap warga negara yang mencakup seluruh aspek kehidupan: ekonomi, politik, pengetahuan, dan kesempatan. ${ }^{27}$ Pada sila kelima butir kedua tertulis mengembangkan sikap adil terhadap sesama, kemudian pada butir keempat disebutkan menghormati hak orang lain. Hal ini kembali menegaskan bahwa Pancasila sebagai dasar Negara Indonesia telah menunjukkan posisi yang sangat mengayomi dan adil terhadap seluruh warga negara Indonesia.

Beberapa fakta ini tentu menunjukkan bahwa Pancasila dengan operasionalisasinya yang tertuang alam butir-butir pada silanya, kemudian dengan konstitusi tertulisnya yaitu Undang-Undang Dasar 1945 baik sebelum amandemen maupun sesudah amandemen ataupun produk hukum lainnya. Hal tersebut menunjukkan bahwa negara dengan ideologi Pancasila dan dasar hukum lainnya telah memberi sebuah bukti bagaimana Pancasila merupakan sebuah ideologi yang meletakkan harkat dan martabat manusia sama atau tidak ada perbedaaan karena asal usul ataupun bentuk fisik yang berbeda.

Apabila kita telaah dari butir-butir yang ada dan merupakan penjelmaan sila persila, maka akan terlihat bahwa dari sepuluh butir pada sila kedua terdapat enam butir yang menyatakan secara garis besar tentang penghormatan terhadap nilai-nilai kemanusiaan, kemudian pada sila kelima terdapat dua butir yang langsung berkaitan dengan penghormatan orang lain. Hal ini membuktikan bahwa bangsa ini merupakan bangsa yang sangat beradab dan meletakan posisi manusia sebagai individu yang telah dijamin dan dilindungi haknya dan terdapat pengakuan kesetaraan dengan manusia lainnya.

Pengembangan sosial budaya dewasa ini harus mengangkat nilai-nilai yang dimiliki bangsa Indonesia sebagai dasar nilai, yaitu nilai Pancasila itu sendiri. Dalam prinsip etika Pancasila pada dasarnya bersifat humanistik, artinya nilai-nilai Pancasila mendasarkan pada nilai yang bersumber pada harkat dan martabat manusia sebagai makhluk yang berbudaya. ${ }^{28}$ Sisi humanistik Pancasila tentu sudah menjadi sebuah hal yang mendarah daging. Isu kesetaraan bagi difabel tentu menjadi sebah hal yang memang harus diperhatikan bersama, bukan seperti pemberian belas kasihan semata. Tetapi memberikan

\footnotetext{
26 Ali Amran, Pendidikan Pancasila Di Perguruan Tinggi (Jakarta: PT. RajaGrafindo Persada, 2016), h 136.

27 Ubaedillah, Pendidikan Kewarganegaraan (Civic Education) Pancasila, Demokrasi Dan Pencegahan Korupsi, Cetakan ke-3:h 257.

28 A. Muchtar Ghazali, PPKn Materi Kuliah Di Perguruan Tinggi (Bandung: PT Remaja Rosdakarya, 2016), h 30 .
} 
sebuah akses yang berkeadilan dan mudah bagi mereka dengan memunculkan kemandiriannya dalam mengakses fasilitas yang menunjang gerak mereka.

Menurut Amartya Sen kebebasan menjadi isu sentral dalam pembangunan karena dua alasan. Pertama alasan evaluatif (penilaian kemajuan pembangunan) dan efektivitas (hasil pembangunan tergantung agen bebas) yang disebut Sen sebagai kebebasan instrumental yaitu : 1) Kebebasan politik; (2) Kesempatan-kesempatan Ekonomi; (3) peluang-peluang sosial; (4) jaminan keterbukaan; (5) Perlindungan keamanan. Khusus bagian kesempatan sosial merujuk pada pengaturan yang memungkinkan masyarakat untuk menikmati pelayanan pendidikan, pemeliharaan kesehatan dan apapun yang dapat menciptakan kemerdekaan bagi semua orang secara layak. ${ }^{29}$ Peluang-peluang sosial sebagai faktor kebebasan instrumental menjadi sebuah bukti, bahwa posisi manusia yang bebas dalam menikmati kebebasan ataupun perlindungan serta jaminan bagi manusia.

Selain itu Durkheim dalam bukunya the Division of Labour in Society, menjelaskan tentang dua tipe solidaritas sosial dalam masyarakat, yaitu solidaritas mekanik dan solidaritas organik. Pokok permasalahan dari dari gagasan atau ide buku tersebut adalah apa yang mengikat atau mempersatukan orang. Hal yang menyatukan adalah kesamaan kepercayaan, cita-cita dan komitmen moral. ${ }^{30}$ Komitmen moral tentu menjadi sebuah hal yang memang harus menjadi sebuah dasar dalam memperjuangkan kesamaan hak bagi penyandang disabiltas. Moral yang salah satu pengertiannya seperti terdapat dalam KBBI (Kamus Besar Bahasa Indonesia) diartikan sebagai sebuah ajaran tentang baik buruk yang diterima umum mengenai perbuatan, sikap, kewajiban, dan sebagainya; akhlak; budi pekerti; susila.

Namun moral dapat menjadi sebuah nilai pada muaranya yang dapat mengatur tingkah laku manusia, dan dengan harapan nantinya akan menjadi sebuah aturan-aturan (rule) yang mengatur sikap (attitude) dan perilaku manusia (human behavior) sehingga dapat menjadi sebuah gerakan kesadaran bagi para penyandang disabilitas. Negara telah melakukan berbagai upaya agar terciptanya kesetaraan di masyarakat khusunya pada kaum difabel. Namun usaha ini tentu tidak akan berarti apa-apa apabila tidak adanya sinergitas yang mendukung upaya tersebut. Semoga dengan semakin majunya negara dan semakin besar pula sumbangsih setiap warga negara untuk mewujudkan asas kesetaraan bagi warga negara.

\section{PENUTUP \\ 1. Simpulan}

Dasar hukum yang ada telah mengakomodir dan melindungi hak kaum disabilitas. Pelaksanaan kesetaran tersebut dalam berbagai bidang tentu memerlukan kesiapan sarana dan prasarana, yang otomatis akan bermuara pada kesiapan anggaran pula. Negara telah berusaha untuk menyediakan dasar hukum terkait dan mulai membenahi fasilitas umum dan berproses untuk membenahi fasilitas sosial. UUD 1945 sudh sangat menjamin hak-hak dasar bagi warga negara, namun terkadang implementasi menjadi sesuatu hal yang sangat rumit. Kerumitan tersebut karena sosialisasi dan hukum yang cenderung, masih baru.

Pada bidang pendidikan, kebanyakan fasilitas sekolah memang belum mengakomodir kaum difabel dan kurangnya Reasonable accomodation bagi penyandang disabilitas. Misalnya tidak adanya lift tangga untuk akses menuju ruang kelas bertingkat. Kemudian letakpapan tulis yang tinggi pun terkadang menyulitkan dan menghambat peserta didik dengan kebutuhan khusus, serta fasilitas lainnya yang masih belum ramah difabel.

\footnotetext{
29 POLITIK PEMB ANGUNAN Paradoks, Teori, Aktor Dan Ideologi, h 66-67.

${ }^{30}$ Damsar, Pengantar Teori Sosiologi (Jakarta: Prenadamedia, 2015), h 88.
} 
Pancasila sebagai ideologi bangsa telah memberikan penghormatan terkait masalah HAM dan kesetaraan manusia. Hal tersebut dapat dilihat melalui butir-butir sila yang memberi gambaran penghormatan dan kesetaraan tersebut. Pancasila memberikan penghargaan dan penghormatan harkat manusia tanpa melihat perbedaannya. Persamaan kesempatan dan hak penyandang diasabilitas dalam berbagai bidang aspek kehidupan merupakan sebuah modal yang sangat berharga bagi pembangunan di Indonesia, serta semoga menjadi sebuah gerakan yang terus membesar dan memberi dampak nyata.

\section{Saran}

Perlindungan hak penyandang disabilitas menjadi sebuah hal yang sangat postif. Namun dasar hukum terkait, perlu disosialisasikan secara masif sehingga unit pelayanan publik terkecil dapat mengetahui hal ini dan dapat memberikan sebuah perbedaan dan pembaharuan dalam melaksanakan aktivitas pelayanannya.

\section{DAFTAR PUSTAKA}

Ali, As'ad Said. Ideologi Gerakan Pasca Reformasi. Jakarta: LP3ES, 2012.

Amran, Ali. Pendidikan Pancasila Di Perguruan Tinggi. Jakarta: PT. RajaGrafindo Persada, 2016.

Damsar. Pengantar Teori Sosiologi. Jakarta: Prenadamedia, 2015.

Ghazali, A. Muchtar. PPKn Materi Kuliah Di Perguruan Tinggi. Bandung: PT Remaja Rosdakarya, 2016.

Irwanto, Eva Rahmi Kasim, Asmin Fransiska, Lusli Mimi, and Okta Siradz. Analisis Situasi Penyandang Disabilitas Di Indonesia : Sebuah Desk Review. Jakarta: Pusat Kajian Disabilitas FISIP UI, 2010.

Joga, Nirwono. "Mewujudkan Kota Ramah Disabilitas." Investor Daily, 2016. http://id.beritasatu.com/home/mewujudkan-kota-ramah-disabilitas/148721.

Komnas Perempuan. "Siaran Pers Komnas Perempuan: Catatan Komnas Perempuan 33 Tahun Ratifikasi Konvensi CEDAW Di Indonesia," July 24, 2017. https://www.komnasperempuan.go.id/reads-siaran-pers-komnas-perempuancatatan-komnas-perempuan-33-tahun-ratifikasi-konvensi-cedaw-di-indonesia.

Latif, Yudi. Negara Paripurna Historisitas, Rasionalitas, Dan Aktualisasi Pancasila. Jakarta: PT Gramedia Pustaka Utama, 2011.

Satriawan, M. Iwan, and Siti Khoiriah. Ilmu Negara. Jakarta: PT. RajaGrafindo Persada, 2016.

Ubaedillah, A. Pendidikan Kewarganegaraan (Civic Education) Pancasila, Demokrasi Dan Pencegahan Korupsi. Vol. Cetakan ke-3. Jakarta: Prenadamedia, 2016. 
El-Mashlahah, Vol. 9, No. 2, 2019

Umi, Sumbulah, ed. Spektrum Gender Kilasan Inklusi Gender Di Perguruan Tinggi. Malang: UIN Malang Press, 2008.

Warjio. POLITIK PEMBANGUNAN Paradoks, Teori, Aktor Dan Ideologi. Jakarta: Kencana, 2016.

World Confenderation for Physical Therapy. The Standard Rules on the Equalisation of Opportunities for Persons with Disabilities. New York: United Nations, 1993. https://www.wcpt.org/sites/wcpt.org/files/files/END_UN_Rules_equalisation_pers ons_disabilities_2015.pdf.

Convention against Torture and Other Crue l, Inhuman or Degrading Treatment or Punishment, 1984. https://www.ohchr.org/Documents/ProfessionalInterest/cat.pdf.

Convention on the Rights of Persons with Disabilities (CRPD). United Nations, 2008. https://www.ohchr.org/Documents/Publications/AdvocacyTool_en.pdf.

Peraturan Daerah Provinsi Kalimantan Selatan Nomor 17 Tentang Perlindungan Dan Pemenuhan Hak Penyandang Disabilitas. Banjarmasin: Pemerintah Provinsi Kalimantan Selatan, 2013. http://banjarmasin.bpk.go.id/wpcontent/uploads/2014/09/PERDA-NO-17-TAHUN-2013-DISABILITAS.pdf.

Peraturan Menteri Pendidikan Nasional No. 70 Tentang Tentang Pendidikan Inklusif Bagi Peserta Didik Yang Memiliki Kelainan Dan Memiliki Potensi Kecerdasan Dan/Atau Bakat Istimewa. Jakarta: Kementrian Pendidikan Nasional, 2009. http://kelembagaan.ristekdikti.go.id/wp-content/uploads/2016/11/Permen-No.-702009-tentang-pendidiian-inklusif-memiliki-kelainan-kecerdasan.pdf.

Peraturan Pemerintah Nomor 43 Tahun 1998 Tentang Upaya Peningkatan Kesejahteraan Sosial Penyandang Cacat. 1998th ed. Jakarta: Sekretaris Negara, n.d. https://www.bphn.go.id/data/documents/98pp043.pdf.

Survei Sosial Ekonomi Nasional 2013. Jakarta: Direktorat Statistik Kesejahteraan Rakyat dan Direktorat Statistik Harga - Badan Pusat Statistik, 2014. https://microdata.bps.go.id/mikrodata/index.php/catalog/220.

Undang-Undang No. 4 Tahun 1997 Tentang Penyandang Cacat. Jakarta: Mentri Sekretaris Negara, 1997. http://www.kpai.go.id/files/uu/UU-NOMOR-4-TAHUN1997-TENTANG-PENYANDANG-CACAT.pdf.

Undang-Undang Dasar 1945. Jakarta: Sekretariat Negara, 2002. http://jdih.pom.go.id/uud1945.pdf.

Undang-Undang No 8 Tahun 2016 Tentang Penyandang Disabilitas. Jakarta: Kementrian Hukum dan HAM, 2016.

Undang-Undang No 20 Tahun 2003 Tentang Sistem Pendidikan Nasional. Jakarta: Kementrian Pendidikan Nasional, 2003. https://kemenag.go.id/file/dokumen/UU2003.pdf. 
United Nations: Convention on the Elimination of All Forms of Discrimination Against Women.” International Legal Materials 19, no. 01 (January 1980): 33-45.

UU No. 25 Tahun 2009 Tentang Pelayanan Publik. Jakarta: Kementrian Hukum dan HAM, 2009. http://bphm.unila.ac.id/images/bphm/doc/UU-No-25-Thn-2009-ttgPelayanan-Publik.pdf. 